\title{
Study and Analysis of the Implementation of 4.0 Technologies in the Agri-Food Supply Chain: A State of the Art
}

\author{
Paula Morella ${ }^{1, *(D)}$, María Pilar Lambán ${ }^{1} \mathbb{D}$, Jesús Royo ${ }^{1} \mathbb{D}$ and Juan Carlos Sánchez ${ }^{2} \mathbb{D}$ \\ 1 Design and Manufacturing Engineering Department, Universidad de Zaragoza, 50018 Zaragoza, Spain; \\ plamban@unizar.es (M.P.L.); jaroyo@unizar.es (J.R.) \\ 2 Smart Systems, Tecnalia, Basque Research and Technology Alliance (BRTA), 20009 Donostia-San Sebastian, \\ Spain; jcarlos.sanchez@tecnalia.com \\ * Correspondence: pmorella@unizar.es
}

check for updates

Citation: Morella, P.; Lambán, M.P.; Royo, J.; Sánchez, J.C. Study and Analysis of the Implementation of 4.0 Technologies in the Agri-Food Supply Chain: A State of the Art. Agronomy 2021, 11, 2526. https://doi.org/ 10.3390 /agronomy 11122526

Academic Editor: Rosa Maria Fanelli

Received: 21 October 2021

Accepted: 8 December 2021

Published: 13 December 2021

Publisher's Note: MDPI stays neutral with regard to jurisdictional claims in published maps and institutional affiliations.

Copyright: (c) 2021 by the authors. Licensee MDPI, Basel, Switzerland. This article is an open access article distributed under the terms and conditions of the Creative Commons Attribution (CC BY) license (https:// creativecommons.org/licenses/by/ $4.0 /)$.

\begin{abstract}
Industry 4.0 is changing the industrial environment. Particularly, the emerging Industry 4.0 technologies can improve the agri-food supply chain throughout all its stages. This study aims to highlight the benefits of implementing Industry 4.0 in the agri-food supply chain. First, it presents how technologies enhance the agri-food supply chain development. Then, it identifies and highlights the most common challenges that Industry 4.0 implementation faces in agri-food's environment. After that, it proposes key performance indicators to measure the advantages of this implementation. To achieve this, a systematic literature review was conducted. It combined conceptual and bibliometric analyses of 78 papers. As a result, the most suitable technologies were identified, e.g., Internet of Things, Big Data, blockchain and cyber physical systems. The most used indicators are proposed and the challenges of implementation were detected and classified in three groups, i.e., technical, educational and governmental. This paper highlights and exemplifies the benefits of implementing Industry 4.0 facing the lack of knowledge that exists nowadays. Moreover, it fulfils the gaps in literature, i.e., the lack of information about the implementation of technologies 4.0 or the description of the most relevant indicators for Industry 4.0 implementation.
\end{abstract}

Keywords: smart industry; agri-food; digitization; key performance indicators

\section{Introduction}

Throughout history, there have been different industrial revolutions that have allowed improvements and technological advances to be implemented. The latest industrial revolution is Industry 4.0, which refers to a new way of working, communicating and relating, based on the connectivity provided by the implementation of the internet and the use of information through the automatic collection and processing of data [1]. The properties that characterize Industry 4.0 are: automation, digitization, decentralization, virtualization, the acquisition of data in real-time and its processing and communication in real-time [2].

Regarding the agri-food industry, it has a crucial role in processing the agricultural raw materials and supplying food [3]. However, this industry is not considered as a sector with high research intensity [4] and rural enterprises are not convinced to participate in collaborative networks to stimulate innovation [5]. The appearance of new business models demands new requirements in the agri-food industry [6,7]. Moreover, innovation strategies have a positive impact on financial performance [8]. Particularly, Forman and Annala (2011) interviewed 733 small enterprises, concluding that "the degree of innovation capabilities, R\&D investments and profitability are associated with the diversity of developed innovation types" [9]. Based on the above, a company that wants to maintain a competitive position must be able to combine high-quality products and services with tight delivery times, all at a low cost. To achieve these objectives, it is essential to obtain information in real time, which 4.0 technologies provide. This real-time information converted into suitable indicators allows the agri-food supply chain (AFSC) to generate improvement 
actions and evaluate the changes and decision making in real time [10]. Therefore, key performance indicators (KPIs) are crucial to check the correct implementation of technologies in AFSC [11]. KPIs are numbers that reflect the productive process of industries in a compact way and, as a management tool, they provide the opportunity for a quick analysis. They ensure that the information acquired from the processes is treated correctly, updated and presented in a comprehensive and easy-to-understand way [11].

The implementation of Industry 4.0 in the AFSC is a way to improve the production processes, increase productivity and reflect individual demands and short-term management wishes $[12,13]$. Furthermore, these technologies are gaining importance for their ability to improve food safety, shelf life and nutritional and sensory qualities [14-19]. For example, Jagtap and Rahimifard (2019) present a case study in which the reduction in food waste improved thanks to the acquisition of real-time data [20].

This paper aims to highlight the potential that Industry 4.0 technologies can bring, to improve the AFSC and fill the gaps in current literature. Kittipanya-ngam and Tan (2020) assert that there is a lack of information on the digitization of the AFSC [21]. Other previous studies demand the need for research on how 4.0 technologies can improve the AFSC [22-25]. Finally, Joppen (2019) identifies the absence of transparency relative to the effects and benefits of Industry 4.0, which could be measured by KPIs [11].

The rest of the manuscript is organized as follows: In Section 2, we describe the methodology of this study. Section 3 presents the results obtained from the study and the paper ends with conclusions and proposals for future research agendas, in Section 4.

\section{Methods}

Based on the gaps identified in Section 1, there is a lack of information about Industry 4.0 implementation in the AFSC, its benefits and how KPIs enhance this analysis. Therefore, it is necessary to compile a literature review to fill those gaps by exploring the use of technologies 4.0 throughout the AFSC.

A systematic literature review (SLR) was conducted. This tool enhances the evaluation of the state of art and the specification of the research questions [26]. An SLR allows us to identify, evaluate and interpret the available and relevant research topic's information, promoting guidelines to identify relevant contributions [27].

Following the methodology presented in Kitchenman (2007) [28], this research study combined bibliometric and conceptual analyses guided by specific research questions (RQs) (see Figure 1).

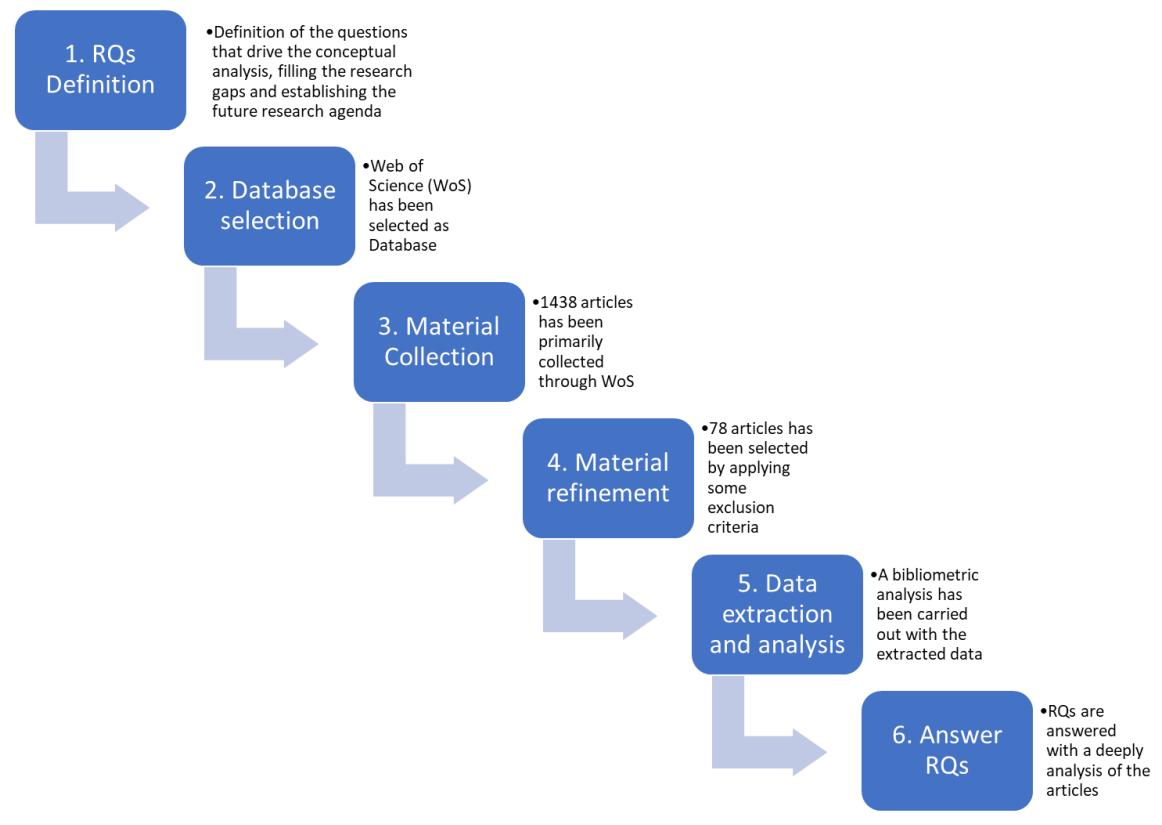

Figure 1. Research methodology. 


\subsection{RQs Definition}

RQs were formulated to identify the principal aspects of applying Industry 4.0 concepts to the AFSC (see Table 1).

Table 1. Research question definition.

\begin{tabular}{ll}
\hline \multicolumn{1}{c}{ Research Question } & \multicolumn{1}{c}{ Motivation } \\
\hline $\begin{array}{l}\text { RQ1: How is research on using Industry 4.0 } \\
\text { to develop AFSCs evolving? }\end{array}$ & $\begin{array}{l}\text { Industry 4.0 is revolutionizing the industrial } \\
\text { environment. }\end{array}$ \\
\hline $\begin{array}{l}\text { RQ2: Which are the most relevant } \\
\text { technologies for AFSC development? }\end{array}$ & $\begin{array}{l}\text { There is not a specific research study about the use } \\
\text { of 4.0technologies; therefore, our RQ2 pretends to } \\
\text { fulfil this gap [21]. }\end{array}$ \\
\hline $\begin{array}{l}\text { RQ3: Which are the most relevant } \\
\text { indicators for the AFSC? }\end{array}$ & $\begin{array}{l}\text { The selection of the appropriate indicators to know } \\
\text { the status of a supply chain is essential [11]. }\end{array}$ \\
$\begin{array}{l}\text { RQ4: What are the challenges of } \\
\text { implementing Industry 4.0 in an AFSC? }\end{array}$ & $\begin{array}{l}\text { The challenges' identification is crucial to succeed } \\
\text { in implementing Industry 4.0. }\end{array}$ \\
\hline
\end{tabular}

\subsection{Database Selection}

Web of Science (WoS) was selected as database because of its ability to identify "high quality" journals [29], even though some authors maintain that using different databases implies better results, such as Scopus and WoS [30]. The truth is that WoS and Scopus complement each other [31]. As the largest proportion of journals is in WoS [32], we chose WoS as database.

\subsection{Material Collection}

The articles from WoS were collected in October 2021 following the following search criteria in topic and key words: (Agro* OR Agri* OR Food) and (Industry 4.0 OR 4.0 OR smart OR intelligen* OR technolog* OR digit*) and (supply chain OR process OR logistic* OR traceab* OR Industr*). The * implies that all the words searched started with these syllables but could have different endings, e.g., technolog* included the search of technology, technological, or technologies. Our study was framed around 1438 articles related to Industry 4.0 and AFSC.

\subsection{Material Refinement}

All the documents were analyzed to avoid bias and ensure that papers referred to the concepts that were investigated [26]. Documents were excluded if they met at least one of these requirements $(\mathrm{R})$ :

- R1: the paper was not in English;

- R2: the paper was not an article;

- R3: The article was published before 2017;

- R4: The category of the article was unrelated to the research topic;

- $\quad$ R5: The key words or the title were unrelated to the researched topic.

We conducted a complementary search for KPIs of the AFSC because a global search for technologies 4.0 and KPIs in AFSC could have proved to be more complex. Moreover, papers related to KPIs seemed to be published before 2017, so they were excluded, by R3, in the first search. We used the keywords (Agro* OR Agri* OR Food) and (supply chain OR process OR logistic* OR traceab* OR Industr*) and (performance OR indicator OR key performance indicator. These papers followed the same exclusion criteria, except R3, and 24 papers were added to the research study. Figure 2 presents how the selection process was performed and how many papers were excluded per requirement. 


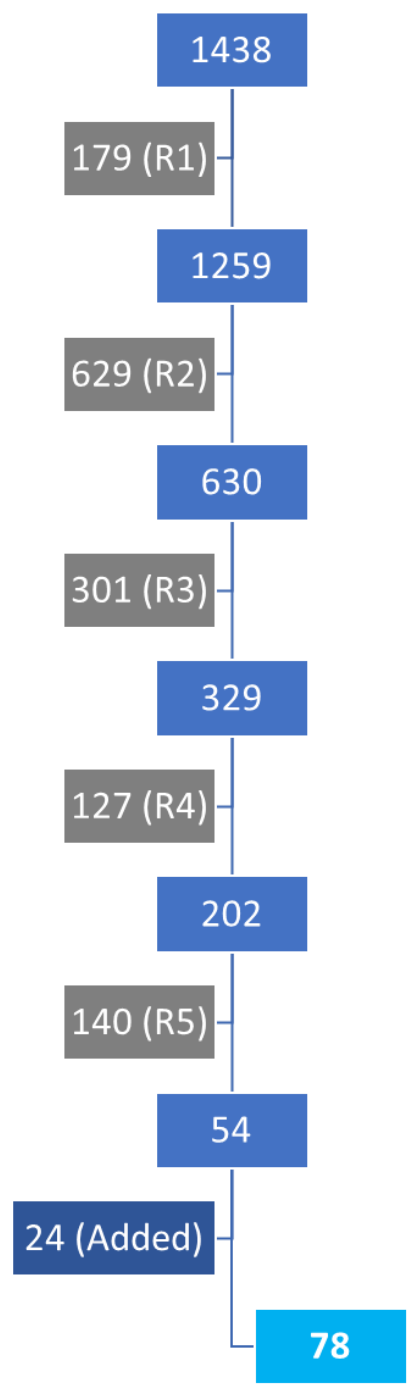

Figure 2. Material refinement scheme.

\subsection{Data Extraction and Analysis}

The 78 articles were analyzed to conduct a bibliometric analysis, which enhanced the answer to RQ1.

\subsection{Answer to RQs}

A conceptual analysis was conducted to answer the other RQs.

\section{Results and Discussion}

This section answers the RQs formulated in Section 2.1 through the analysis of the 78 collected articles.

\subsection{RQ1. How Is Research on Using Industry 4.0 to Develop AFSCs Evolving?}

RQ1 was answered by conducting a bibliometric analysis. The study attended to the distribution of publications per year, journal and country, as well as the most cited articles and keywords.

Concerning the distribution by year of publication, the largest number of articles were published in the last three years. This finding confirms the growing relevance of Industry 4.0 in the AFSC development (see Figure 3). 


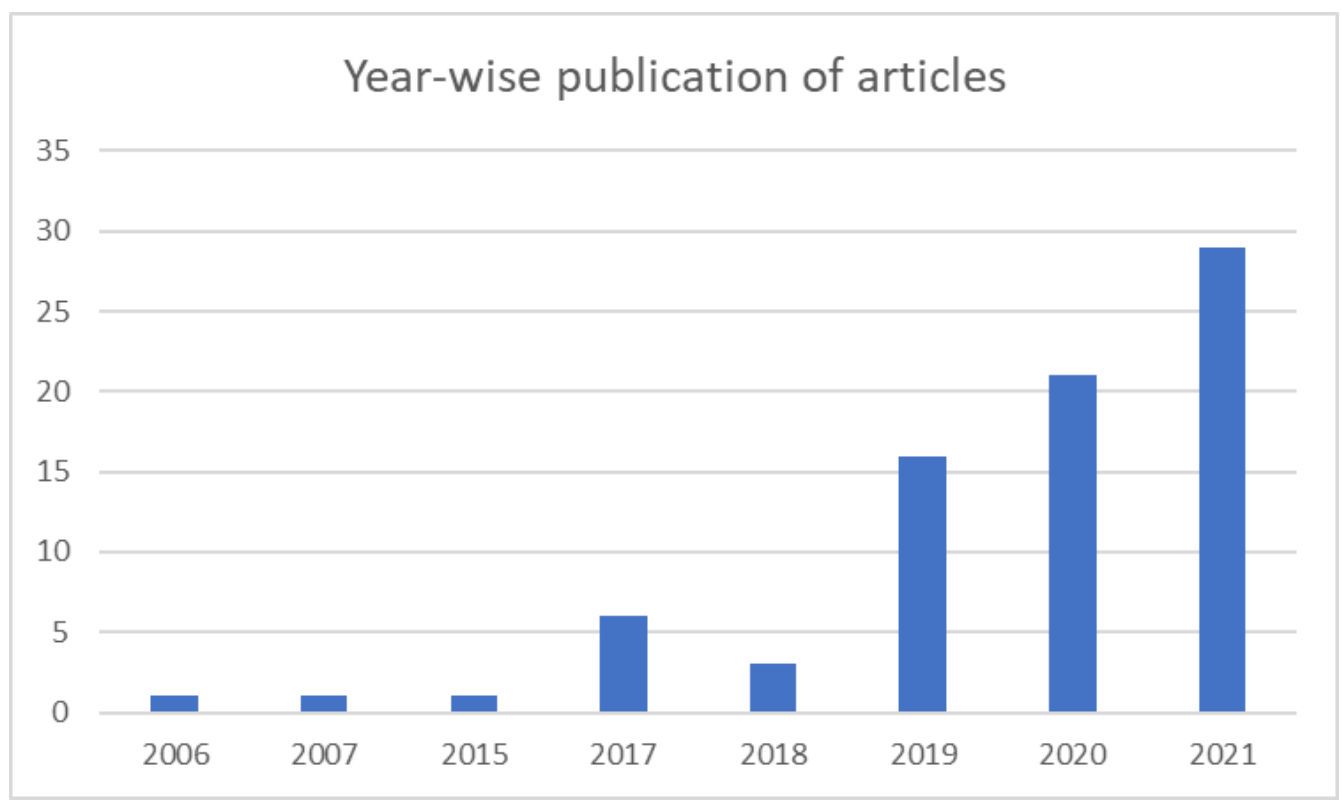

Figure 3. Number of publications per year.

Regarding journals' distribution, Sustainability, Journal of Cleaner Production and Computers and Electronics in Agriculture appeared as the most common journals for publication (see Figure 4). Forty-nine journals published the 78 papers with about $75 \%$ of journals publishing only 1 article. These results support the idea that the relevance of this topic is increasing, as it is widespread among lots of journals. The most cited articles can be seen in Table 2.

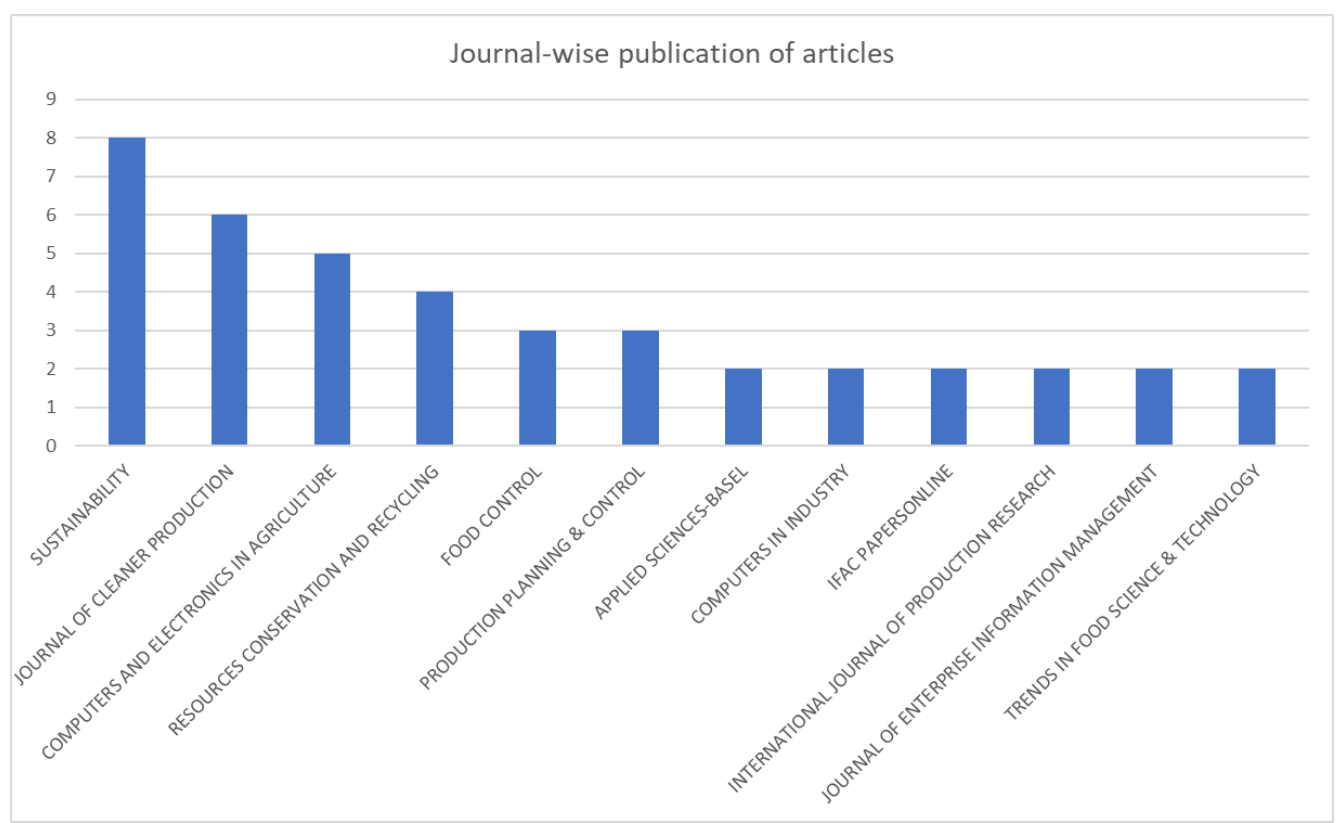

Figure 4. Journal-wise publication of articles. 
Table 2. Most cited articles.

\begin{tabular}{cc}
\hline Reference & Number of Citations \\
\hline$[33]$ & 190 \\
\hline$[34]$ & 138 \\
\hline$[35]$ & 136 \\
\hline$[36]$ & 122 \\
\hline$[37]$ & 91 \\
\hline
\end{tabular}

Figure 5 presents the distribution of publications per country, China and Italy being the countries with the most numerous publications on this topic.

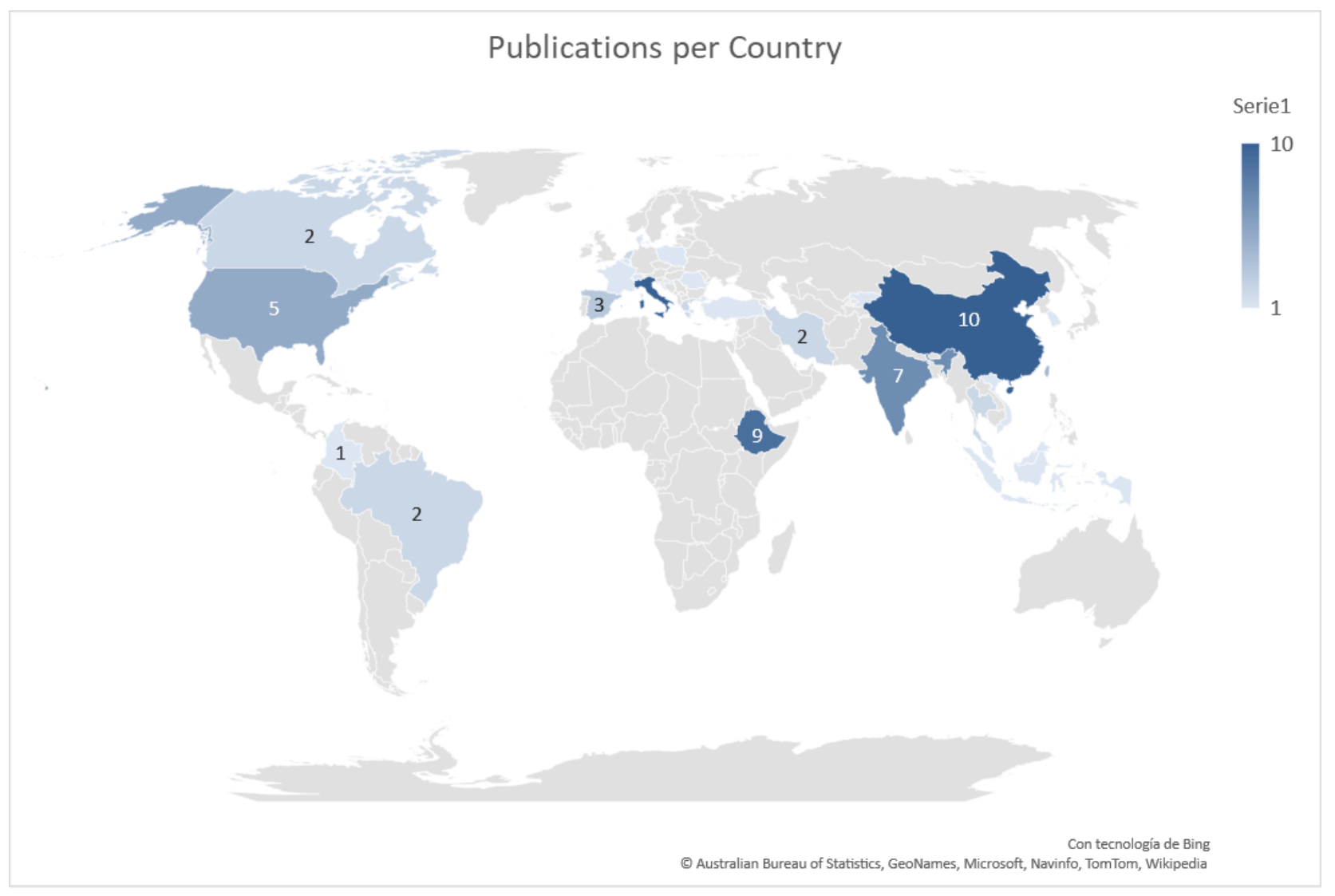

Figure 5. Publications per country.

Finally, the keywords per year were studied. Figure 6 presents when each keyword appeared for the first time. Industry 4.0 appeared in 2007 and grew significantly in the following years. Indicators lost importance with the passage of time, whereas sustainability and traceability gained importance since 2017.

The bibliometric analysis showed that the interest in the implementation of Industry 4.0 in the AFSC grew sharply in the last three years, together with the concepts of sustainability and traceability. However, the topic of indicators should be re-driven, because it has lost strength, but it is essential to measure the results of the implementation of Industry 4.0. 


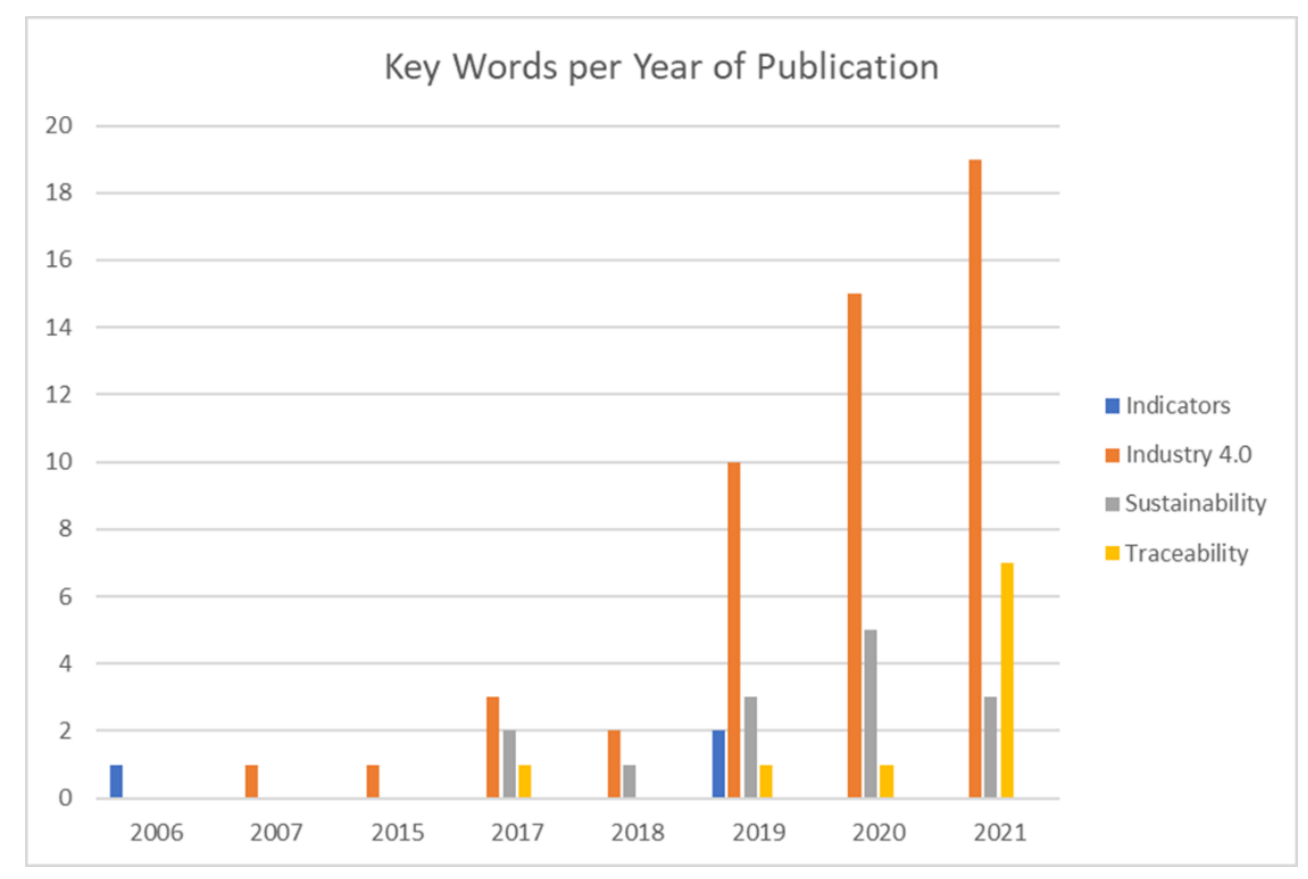

Figure 6. Keywords per year.

\subsection{RQ2. Which Are the Most Relevant Technologies for AFSC Development?}

Following the bibliometric analysis, the evolution of technologies in AFSC could be examined (see Figure 7). Cyber physical systems (CPSs) appeared as the first technology in 2015. Other technologies, i.e., Internet of Things (IoT), Big Data and blockchain gained importance in the last two years. On the contrary, technologies such as digital twin, cloud computing and augmented reality (AR) were not so applied to the agricultural world.

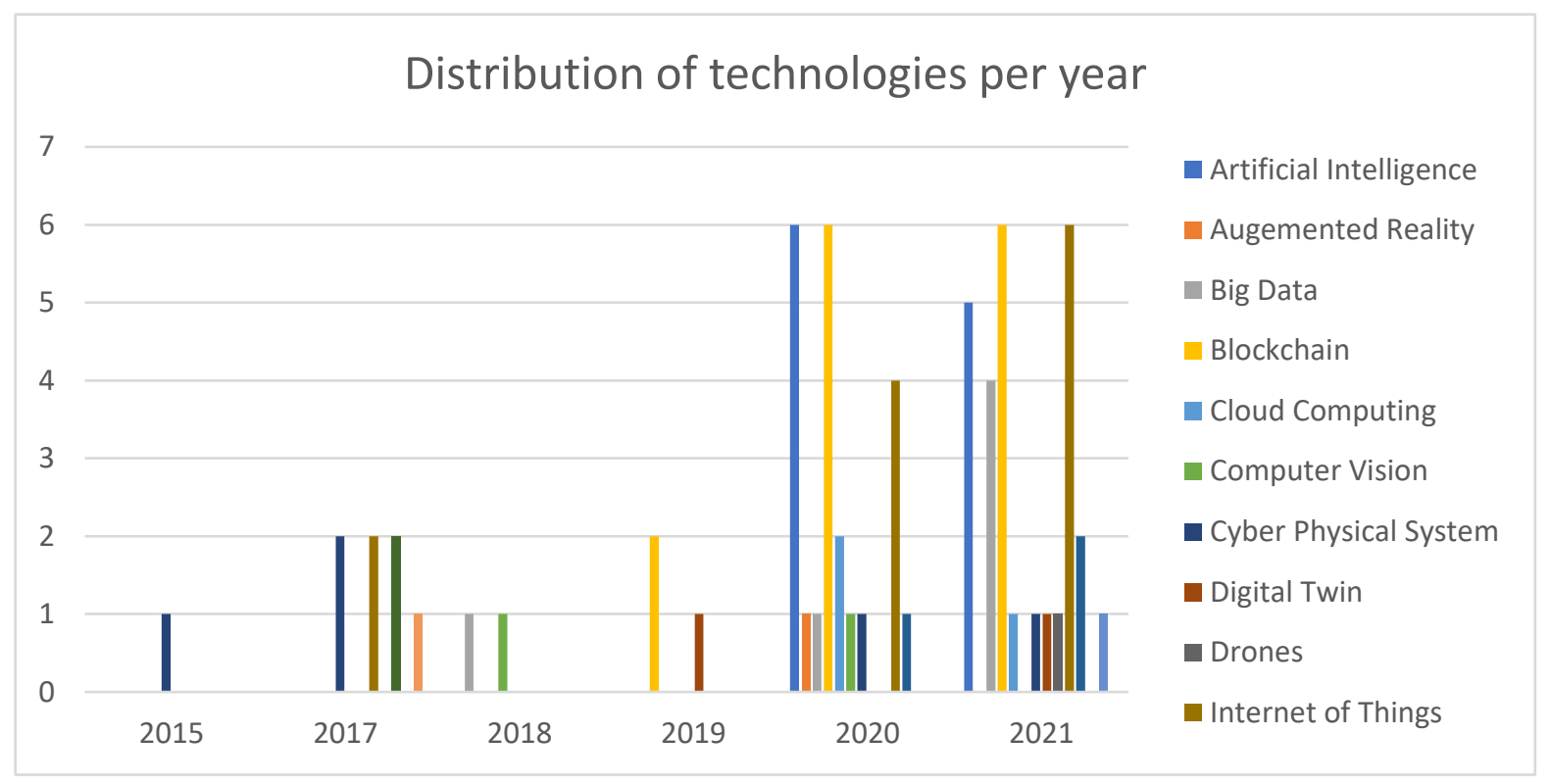

Figure 7. Distribution of technologies per year.

We analyzed technologies and keywords together to detect which technologies were applied the most to each issue of the AFSC (see Figure 8). As assumed, all technologies were linked to Industry 4.0, with IoT being the most mentioned one. In the case of traceability, the implemented technologies were blockchain, cloud computing and radio frequency identification (RFID), while sustainability was supported by technologies such as IoT, 
virtual reality (VR), CPS, computer vision, AR and artificial intelligence (AI). This analysis showed that the issue of indicators in the AFSC was not related to 4.0 technologies. This finding reinforces the idea that the relationship between Industry 4.0 and KPIs should be reviewed.

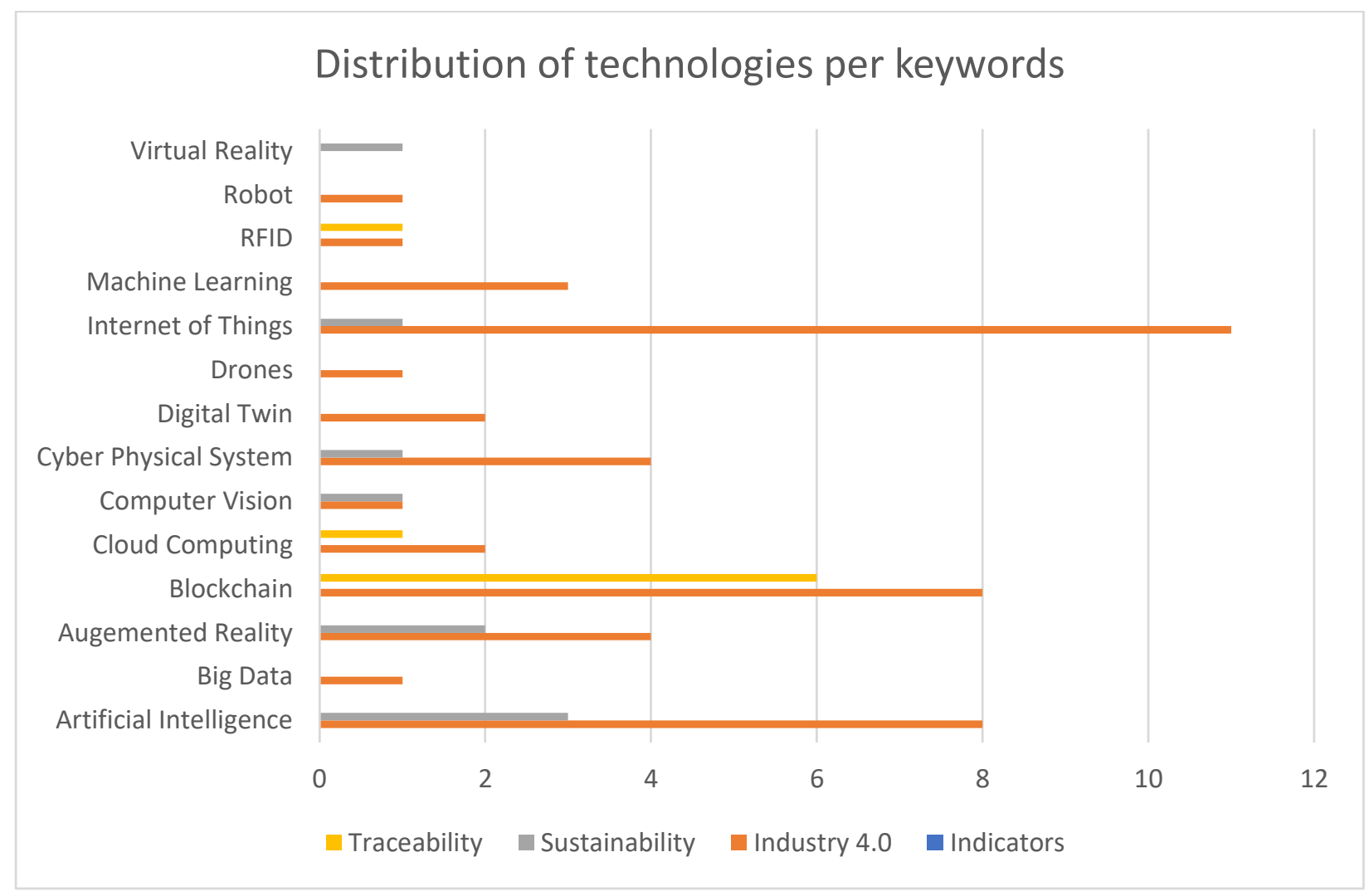

Figure 8. Distribution of technologies per keyword.

The use cases of technologies in the AFSC were studied and the results are summarized in Table 3.

AI can detect, predict, or diagnose undesirable situations in industrial systems. This technology replaces or reduces human-made controls in food production and delivery processes, which are often unreliable and time-consuming [38]. AI helps in preventing or minimizing downtime and the persistence of dangerous situations [39]. In addition, it is often used in tasks related to the quality and classification of food in operational processes [40,41]. In [42], interesting issues about AI are highlighted towards a space economy to achieve sustainable and responsible agri-food business models.

Big data provide solid data support that can innovate the economic management of the entire AFSC [43] or, in conjunction with other technologies, develop a smart agriculture supporting key data of agricultural aspects, e.g., weather, geographical spatialization and animal and crop behaviors $[44,45]$.

In the case of blockchain, as seen in Figure 7, this is closely related to traceability. Traceability is a topic associated with the quality and the security of the products [46-48]. Blockchain technology is very useful to improve the security and supply of food and guarantees transparency to the customer along the entire AFSC [22,37,49-56]; further, it can also reduce the costs in comparison with the traditional system [57]. RFID complements this technology for identification tasks $[7,37]$.

CPSs have different applications to the AFSC. Chen (2017) presented a new approach to CPSs used in food traceability based on intelligent value stream integrated with enterprise architectures and a value stream mapping method by fog computing network 
for collaborative traceability efficiency [58]. Pal and Kant (2020) proposed to turn fresh food logistics into a CPS that monitors and controls the associated operating system [59]. This could improve the freshness and safety of food, reduce food waste and increase the efficiency of transportation and distribution. CPSs can be also used to develop precision agriculture $[60,61]$.

In general, the digital twin is used in process simulation and production scheduling for operational processes [62]. Dey et al. (2021) showed a particular case of simulation of the thermal behavior of fruit to help to improve cooling processes [63].

IoT allows the collection of data that can affect the quality of food and its traceability along the AFSC [34,64-66]. It can also help to increase productivity, efficiency and performance and providing machine data and information to improve operational processes [67,68] or key aspects of crops and animals for agricultural monitoring [44].

Considering sustainability, in the AFSC, the most common topics were reducing food waste and surpluses in operational processes [69-73] and improving energy efficiency $[72,74]$. There are some technologies that seek to bring this sustainability topics closer to the AFSC, i.e., AI by reducing food waste [35,75-78]; Big Data by enhancing the achievement of the Sustainable Development Goals (SDG) related to safety, traceability and food quality [79]; CPSs by helping with the implementation of the life-cycle analysis (LCA) [80]; and IoT by improving the energy efficiency of the AFSC [81].

Table 3. Articles distributed by technologies.

\begin{tabular}{|c|c|c|c|c|c|c|c|c|c|c|c|c|c|c|}
\hline Reference & AI & AR & $\begin{array}{l}\text { Big } \\
\text { Data }\end{array}$ & Blockchain & $\begin{array}{c}\text { Cloud } \\
\text { Computing }\end{array}$ & $\begin{array}{l}\text { Computer } \\
\text { Vision }\end{array}$ & CPS & $\begin{array}{c}\text { Digital } \\
\text { Twin }\end{array}$ & Drones & IoT & $\begin{array}{l}\text { Machine } \\
\text { Learning }\end{array}$ & RFID & Robot & VR \\
\hline [82] & $\times \times$ & & & & & & & & & & & & & \\
\hline [40] & $\times$ & & & & & & & & & & & & & \\
\hline [42] & $\times$ & & & & & & & & & & & & & \\
\hline [83] & $x$ & & $\times$ & $\times$ & & & & & & $\times$ & & & & \\
\hline [84] & $x$ & & & & $x$ & & & & & & $\times$ & & & \\
\hline [41] & $x$ & $\times$ & & & & & & & & & & & & \\
\hline [35] & & & & & & $\times$ & & & & & & & & \\
\hline [75] & $x$ & & & & & & & & & $\times$ & & & & \\
\hline [38] & $x$ & & . & & & & & & & & $x$ & & & \\
\hline [43] & & & $\times$ & & & & & & & & & & & \\
\hline [44] & & & $x$ & & & & & & $\times$ & $\times$ & & & & \\
\hline [45] & & & $x$ & & & & & & & $x$ & & & & \\
\hline [21] & & & & $\times$ & & & & & & & & & & \\
\hline [49] & & & & $x$ & & & & & & & & & & \\
\hline [85] & & & & $x$ & & & & & & & & & & \\
\hline [51] & & & & $x$ & & & & & & & & & & \\
\hline [50] & & & & $x$ & & & & & & & & & & \\
\hline [22] & & & & $x$ & & & & & & & & & & \\
\hline [36] & & & & $x$ & & & & & & & & & & \\
\hline [52] & & & & & & & & & & $\times$ & & & & \\
\hline [58] & & & & & & & $\times$ & & & & & & & \\
\hline [59] & & & & & & & $x$ & & & & & & & \\
\hline [60] & & & & & & & $x$ & & & & & & & \\
\hline [61] & & & & & & & $x$ & & & & $x$ & & $\times$ & \\
\hline [62] & & & & & & & & $x$ & & & & & & \\
\hline [63] & & & & $x$ & $x$ & & & & & & & & & \\
\hline
\end{tabular}


Table 3. Cont.

\begin{tabular}{|c|c|c|c|c|c|c|c|c|c|c|c|c|c|c|}
\hline Reference & AI & AR & $\begin{array}{l}\text { Big } \\
\text { Data }\end{array}$ & Blockchain & $\begin{array}{c}\text { Cloud } \\
\text { Computing }\end{array}$ & $\begin{array}{c}\text { Computer } \\
\text { Vision }\end{array}$ & CPS & $\begin{array}{c}\text { Digital } \\
\text { Twin }\end{array}$ & Drones & IoT & $\begin{array}{l}\text { Machine } \\
\text { Learning }\end{array}$ & RFID & Robot & VR \\
\hline [53] & & & & & & & & $x$ & & & & & & \\
\hline [86] & & & & & $x$ & & & & & & & & & \\
\hline [64] & & & & & & & & & & $\times$ & & & & \\
\hline [65] & & & & & & & & & & $x$ & & & & \\
\hline [67] & & & & & & & & & & $\times$ & & & & \\
\hline [34] & & & & & & & & & & $x$ & & & & \\
\hline [68] & & & & & & & & & & $x$ & & & & \\
\hline [66] & & & & & & & & & & $\times$ & & & & \\
\hline [87] & & & & & & & & & & & & $\times$ & & \\
\hline [76] & $x$ & & & & & & & & & & & & & \\
\hline [77] & $\times$ & & & & & & & & & & & & & \\
\hline [78] & $\times$ & & & & & $\times$ & & & & & & & & \\
\hline [79] & & & $\times$ & & & & & & & & & & & \\
\hline [88] & & & $x$ & & & & & & & & & & & \\
\hline [80] & & & & & & & $x$ & & & & & & & $\times$ \\
\hline [81] & & & & & & & & & & $\times$ & & & & \\
\hline [24] & & & & $x$ & & & & & & & & & & \\
\hline [57] & & & & $\times$ & & & & & & & & & & \\
\hline [54] & & & & $x$ & & & & & & & & & & \\
\hline [55] & & & & $\times$ & & & & & & & & & & \\
\hline [56] & & & & $\times$ & & & & & & & & & & \\
\hline [37] & & & & & & & & & & & & $x$ & & \\
\hline
\end{tabular}

AI, artificial intelligence; AR, augmented reality; CPS, cyber physical system; IoT, Internet of Things; RFID, radio frequency identification; VR, Virtual Reality. The $\times$ represents that this technology appears in this reference.

\subsection{RQ3: Which Are the Most Relevant Indicators for the AFSC?}

Measuring variables in real time allows companies to react faster to changing conditions in supply chains. The data or information that companies collect are crucial. In this sense, the technologies of Industry 4.0 can reduce the uncertainty, as they allow to obtain accurate information in real-time. This information helps to increase the efficiency, sustainability, flexibility, agility and the adaptive capacity throughout the entire supply chain [83].

Measuring the performance of AFSCs is not always easy, because they present different characteristics from the rest of the supply chains. In addition, consumer behavior has changed and consumers care more about aspects such as food safety, pesticide use or sensory properties [33]. Interest is growing by controlling production costs, reducing energy consumption and improving efficiency in production due to the low profit margin of some food industries [89]. KPIs enable the control of these aspects. Acquiring information in real time allows more accurate data acquisition and thus KPI calculation to be performed. In this sense, Industry 4.0 technologies, such as CPSs, allow time variables to be acquired and used to obtain more accurate KPIs than before [90]. At the same time, they could be used to measure the benefits of implementing these new technologies. The study on indicators is presented in the following table (Table 4). 
Table 4. Study of KPIs.

\begin{tabular}{|c|c|c|}
\hline KPIs Category & KPI & Reference \\
\hline \multirow{6}{*}{ Ecoefficiency } & Use of energy & \multirow{6}{*}{ [91] } \\
\hline & Greenhouse gas emissions & \\
\hline & Use of water & \\
\hline & Wastewater generation & \\
\hline & Generation of organic waste & \\
\hline & Packaging waste & \\
\hline \multirow{4}{*}{ Transport and Logistics } & Distance traveled & \multirow{4}{*}{ [92] } \\
\hline & Service level & \\
\hline & Stock inventory & \\
\hline & Use of the ruck & \\
\hline \multirow{3}{*}{ Energy consumption } & Specific energy consumption & \multirow{3}{*}{ [93] } \\
\hline & Energy intensity & \\
\hline & Carbon intensity & \\
\hline \multirow{6}{*}{ Performance } & Production costs & \multirow{29}{*}{ [33] } \\
\hline & Distribution costs & \\
\hline & Transaction costs & \\
\hline & Benefits & \\
\hline & Return of investment & \\
\hline & Inventory & \\
\hline \multirow{5}{*}{ Flexibility } & Consumer satisfaction & \\
\hline & Volume flexibility & \\
\hline & Delivery flexibility & \\
\hline & Backorders & \\
\hline & Lost sales & \\
\hline \multirow{6}{*}{ Responsibility } & Fill rate & \\
\hline & Product delay & \\
\hline & Consumer response time & \\
\hline & Lead/production time & \\
\hline & Customers' complaints & \\
\hline & Shipping errors & \\
\hline \multirow{3}{*}{ Sensorial Properties and Duration } & Product appearance & \\
\hline & Taste & \\
\hline & Useful life & \\
\hline \multirow{2}{*}{ Product Safety } & Salubrity & \\
\hline & Product Safety & \\
\hline \multirow{2}{*}{ Reliability and Convenience } & Reliability & \\
\hline & Convenience & \\
\hline \multirow{3}{*}{ Quality } & Traceability & \\
\hline & Warehouse conditions & \\
\hline & Work conditions & \\
\hline \multirow{2}{*}{ Marketing } & Promotion & \\
\hline & Consumer service & \\
\hline
\end{tabular}


Table 4. Cont.

\begin{tabular}{|c|c|c|}
\hline KPIs Category & KPI & Reference \\
\hline \multirow{20}{*}{ Sustainability } & Energy waste & \\
\hline & Water waste & \\
\hline & Use of pesticides & \\
\hline & Recycle/Reuse & \\
\hline & Preservation of biodiversity & \multirow{16}{*}{ [94] } \\
\hline & Soil conservation & \\
\hline & Water preservation & \\
\hline & Air pollution & \\
\hline & $\mathrm{CO} 2$ emissions & \\
\hline & Long-term water pollution & \\
\hline & Long-term soil contamination & \\
\hline & Toxic waste management & \\
\hline & Noise pollution & \\
\hline & Drinking water consumption & \\
\hline & Reuse and recycling of water & \\
\hline & Crop production & \\
\hline & Renewable energy production & \\
\hline & Logistics & \\
\hline & Carbon balance & \\
\hline & Nitrogen balance & \\
\hline
\end{tabular}

Maxime et al. (2006) determined a series of KPIs, related to eco-efficiency, which, in turn, had different sub-indicators [91]. On the other hand, Yuan et al. (2019) presented a series of indicators related to logistics and transportation [92]. Juchniewicz and Lukiewska (2021) also presented indicators related to logistics, e.g., the ratio of exports in the world market or the relationship between quantities of exported and imported products [95].

Morais et al. (2020) determined three KPIs related to energy consumption [93]. Aramyan et al. (2007) presented different KPI categories, e.g., performance, flexibility and responsibility [33]. The indicators of the performance category were also exposed in the article published by Costa et al. (2020), where the authors explain the KPI for the worker's level of experience, which is measured at their time thanks to the two indicators of financial gains and product quality [96]. Fernandes Ferraez et al. (2020) proposed several environmental indicators [94]. Fernandez Mena et al. (2020) proposed environmental indicators to evaluate scenarios in terms of environmental services, nutrient cycles and autonomy of means [97]. Likewise, Ruiz- Almeida and Rivera-Ferre (2019) and Mandarino et al. (2019) also presented a series of environmental indicators [98,99]. The former performed an analysis of the operation of the food systems at an international level, measuring 97 indicators divided into six categories; the latter determined sustainability indicators in industry.

The analyzed indicators were distributed into several categories, as can be seen in Figure 9. After that, the number of KPIs was studied to establish which were the most relevant categories for the AFSC (see Figure 10). 


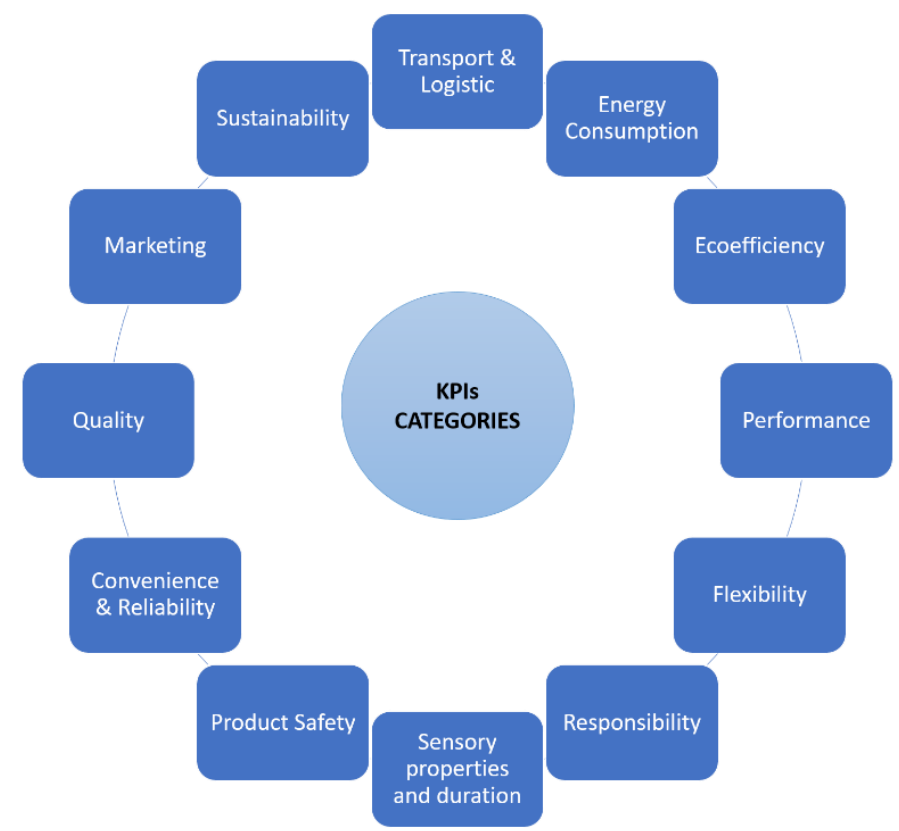

Figure 9. KPI categories.

\section{Distribution of KPIs}
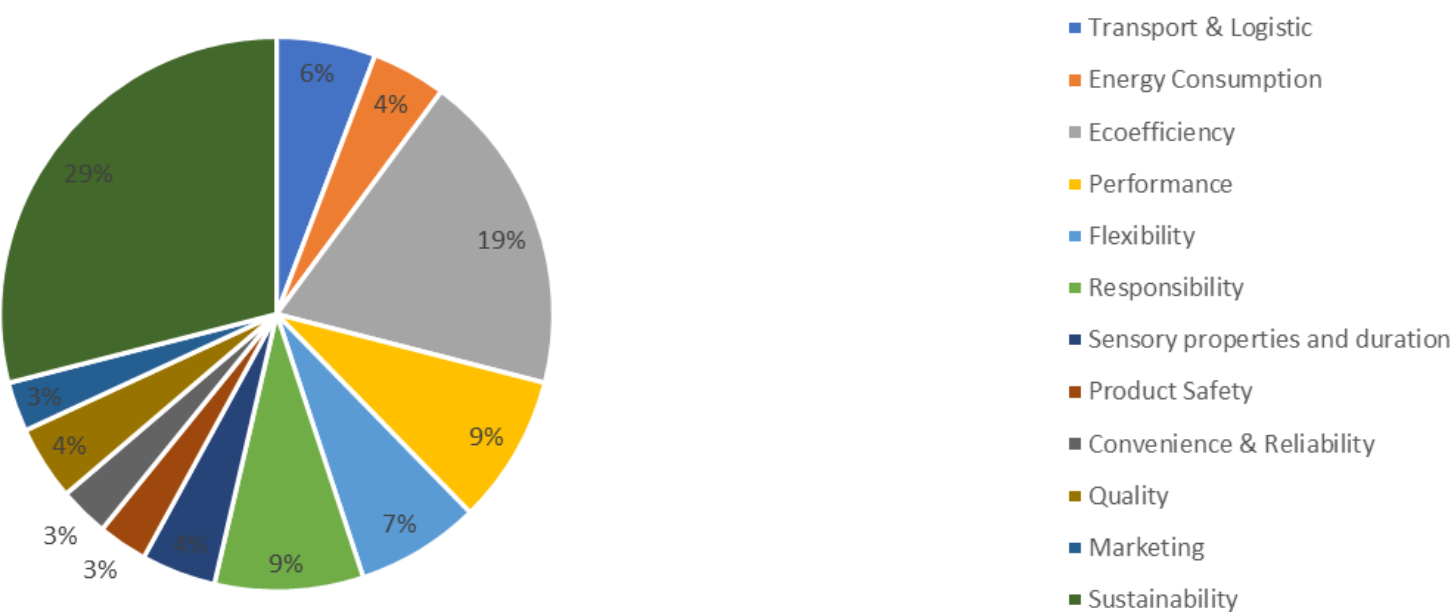

Figure 10. Distribution of KPIs per category.

Figure 10 shows that sustainability was the most relevant category for KPIs in the AFSC, followed by categories such as ecoefficiency, performance and reliability. Future research should be focused on the development of this kind of KPIs and their implementation in the AFSC, helped by 4.0technologies.

\subsection{RQ4: What Are the Challenges of Implementing Industry 4.0 in an AFSC?}

The implementation of 4.0 technologies has a significant impact on the efficiency, productivity and profitability of companies. However, it also requires overcoming a series of practical challenges, mainly due to the lack of modernization and automation of companies [45]. For that reason, this section pretends to highlight the challenges of this implementation; thus, enterprises can identify and overcome them.

This research study reveals that the challenges of implementing 4.0 technologies in the AFSC can be classified into technical, educational and policy challenges and regulatory frameworks. The agri-food industry is embedded into a historical trajectory of resistance to change [100]. According to Conti et al. (2021), there are six thematic explanations of this 
resistance which are closely related to those three groups of challenges [101]. Technical challenges come from "technological persistence" and "infrastructure rigidities"; once a technology is chosen and farmers develop the skills to employ that technology, it turns into a deeply embedded procedure [102]. Educational challenges are associated with "attitudes and cultures that cause aversion to change" and "research priorities, practices and dominant innovation narratives misaligned to the transformational change agenda". When certain practices are adopted and considered as part of the family tradition, they are automatically labelled as the "best" ones [103]. Finally, policy challenges emerge from "misaligned institutional settings, policies and incentives" and "political economy factors that skew the direction of change". The agri-food industry transformation is guided by powerful actors that support their own interests, although they are not often aligned with the development goals of the agri-food system [104].

Regarding technical challenges, Zaraté et al. (2019) stated that it is necessary not only to integrate technologies but also to ensure their interoperability [105]. The diversity of interests and characteristics in the implementation and the heterogeneity of the sector make a single solution difficult. For this reason, group decision making should be encouraged. Another technological challenge is the need for data standards. Standardizing the data would mean equality for all those involved; therefore, it would be possible to access the same information providing a financial gain [83]. Moreover, the traditional structure is not appropriate for the new technologies. This means that there is no suitable infrastructure for the connection established between the physical and digital world $[83,106]$ and that there is a lack of training platforms to develop these technologies [36,107].

Educational challenges are related to lack of awareness and fear of change. Today, professionals are still unaware of the improvements that Industry 4.0 can bring to the AFSC and are not familiar with those technologies $[108,109]$. This lack of acceptance may be due to the lack of real examples of financial viability, coupled with high investment costs $[107,110]$. Furthermore, these challenges mean that there is a lack of technical knowledge to implement and understand these new technologies [111]. To overcome these challenges, this article highlights the uses and benefits of the implementation of 4.0 technologies in the AFSC, enhancing the advantages of the application of these technologies.

Finally, there is a lack of government support. There are no government incentives, financial subsidies, or training programs to reduce implementation costs [112]. In addition, regulatory policies and protocols are necessary for the adoption of new technologies $[36,107]$.

\section{Conclusions and Future Research Agenda}

This study aims to contribute to the knowledge about the advantages and opportunities that Industry 4.0 can bring to the AFSC by identifying the most suitable technologies, introducing the implementation of KPIs and highlighting the challenges of this topic. To achieve this, an SLR was conducted and 78 articles were analyzed in depth.

The study shows that research on Industry 4.0 together with AFSC has sharply increased in recent years. Particularly, the most cited technologies are CPSs, IoT, Big Data and blockchain, the latter being indispensable to develop new traceability projects. Furthermore, the topic of sustainability in the AFSC seems to be closely related with the implementation of technologies such as AI, Big Data, CPSs and IoT to achieve sustainable goals in the environment.

Regarding the implementation of KPIs, Industry 4.0 can enhance their implementation [90]; at the same time, they can measure the benefits of Industry 4.0 [113]. Although the interest in controlling production is growing, the topic of indicators in the AFSC has lost strength in recent years. This research study identifies, as the most important ones, the KPIs related to sustainability, ecoefficiency, performance and reliability.

The challenges faced by Industry 4.0 implementation in the AFSC were classified into three groups: technical, educational and governmental. 
Finally, the following research agenda was developed thinking in terms of fulfilling the gaps and overcoming the challenges found in this research study:

- $\quad$ Studies should be focused on KPI development; thus, KPIs could prove the advantages of implementing 4.0 technologies.

- $\quad$ Research should show successful cases of industry 4.0 implementation in the AFSC to encourage its acceptance.

- There is a lack of standardization in the implementation process, which should be reviewed in future research.

- The interaction between sustainability and Industry 4.0 in the AFSC should be more attentively reviewed.

Author Contributions: Conceptualization, methodology and investigation, P.M. and M.P.L.; validation, M.P.L.; writing-original draft preparation, P.M.; writing-review and editing, M.P.L.; supervision, M.P.L. and J.R.; project administration, J.R. and J.C.S. All authors have read and agreed to the published version of the manuscript.

Funding: This research study received no external funding.

Institutional Review Board Statement: Not applicable.

Informed Consent Statement: Not applicable.

Conflicts of Interest: The authors declare no conflict of interest.

\section{References}

1. Ghobakhloo, M. The future of manufacturing industry: A strategic roadmap toward Industry 4.0. J. Manuf. Technol. Manag. 2018, 29, 910-936. [CrossRef]

2. de Sousa Jabbour, A.B.L.; Jabbour, C.J.C.; Foropon, C.; Godinho Filho, M. When titans meet-Can industry 4.0 revolutionise the environmentally-sustainable manufacturing wave? The role of critical success factors. Technol. Forecast. Soc. Chang. 2018, 132, 18-25. [CrossRef]

3. Bigliardi, B.; Galati, F. Innovation trends in the food industry: The case of functional foods. Trends Food Sci. Technol. 2013, 31, 118-129. [CrossRef]

4. Martinez, M.G. Innovation in the Spanish food \& drink industry. Int. Food Agribus. Manag. Rev. 2000, 3, 155-176. [CrossRef]

5. Fanelli, R.M. Rural Small and Medium Enterprises Development in Molise (Italy). Eur. Countrys. 2018, 10, 566-589. [CrossRef]

6. Stefansdottir, B.; Grunow, M. Selecting new product designs and processing technologies under uncertainty: Two-stage stochastic model and application to a food supply chain. Int. J. Prod. Econ. 2018, 201, 89-101. [CrossRef]

7. Akyazi, T.; Goti, A.; Oyarbide, A.; Alberdi, E.; Bayon, F. A Guide for the Food Industry to Meet the Future Skills Requirements Emerging with Industry 4.0. Foods 2020, 9, 492. [CrossRef]

8. Bigliardi, B. The effect of innovation on financial performance: A research study involving SMEs. Innovation 2013, 15, 245-255. [CrossRef]

9. Forsman, H.; Annala, U. Small enterprises as innovators: Shift from a low performer to a high performer. Int. J. Technol. Manag. 2011, 56, 154. [CrossRef]

10. Morella, P.; Lambán, M.; Royo, J.; Sánchez, J. The Importance of Implementing Cyber Physical Systems to Acquire Real-Time Data and Indicators. J 2021, 4, 147-153. [CrossRef]

11. Joppen, R.; von Enzberg, S.; Gundlach, J.; Kühn, A.; Dumitrescu, R. Key performance indicators in the production of the future. In Proceedings of the 52nd CIRP Conference on Manufacturing Systems (CMS), Ljubljana, Slovenia, 12-14 June 2019; Elsevier: Amsterdam, The Netherlands, 2019; Volume 81, pp. 759-764. [CrossRef]

12. Jambrak, A.R.; Nutrizio, M.; Djekić, I.; Pleslić, S.; Chemat, F. Internet of Nonthermal Food Processing Technologies (IoNTP): Food Industry 4.0 and Sustainability. Appl. Sci. 2021, 11, 686. [CrossRef]

13. Trivelli, L.; Apicella, A.; Chiarello, F.; Rana, R.; Fantoni, G.; Tarabella, A. From precision agriculture to Industry 4.0 Unveiling technological connections in the agrifood sector. Br. Food J. 2019, 121, 1730-1743. [CrossRef]

14. Gimenez-Escalante, P.; Rahimifard, S. A Methodology to Assess the Suitability of Food Processing Technologies for Distributed Localised Manufacturing. Sustainability 2019, 11, 3383. [CrossRef]

15. Martins, I.B.A.; Oliveira, D.; Rosenthal, A.; Ares, G.; Deliza, R. Brazilian consumer's perception of food processing technologies: A case study with fruit juice. Food Res. Int. 2019, 125, 108555. [CrossRef] [PubMed]

16. Manogaran, G.; Hsu, C.-H.; Rawal, B.S.; Muthu, B.A.; Mavromoustakis, C.X.; Mastorakis, G. ISOF: Information Scheduling and Optimization Framework for Improving the Performance of Agriculture Systems Aided by Industry 4.0. IEEE Internet Things J. 2021, 8, 3120-3129. [CrossRef]

17. Michel-Villarreal, R.; Vilalta-Perdomo, E.; Canavari, M.; Hingley, M. Resilience and Digitalization in Short Food Supply Chains: A Case Study Approach. Sustainability 2021, 13, 5913. [CrossRef] 
18. Saryatmo, M.; Sukhotu, V. The Influence of the Digital Supply Chain on Operational Performance: A Study of the Food and Beverage Industry in Indonesia. Sustainability 2021, 13, 5109. [CrossRef]

19. Karbekova, A.B.; Osmonalieva, D.A.; Sadyraliev, Z.; Urmatayim, A.K. The Main Directions of Digital Modernization of the Agro-Industrial Complex of a Modern Region. In Ubiquitous Computing and the Internet of Things: Prerequisites for the Development of ICT; Popkova, E.G., Ed.; Springer: Cham, Switzerland, 2019; Volume 826, pp. 949-955.

20. Jagtap, S.; Rahimifard, S. The digitisation of food manufacturing to reduce waste-Case study of a ready meal factory. Waste Manag. 2019, 87, 387-397. [CrossRef]

21. Kittipanya-Ngam, P.; Tan, K.H. A framework for food supply chain digitalization: Lessons from Thailand. Prod. Plan. Control. 2020, 31, 158-172. [CrossRef]

22. Köhler, S.; Pizzol, M. Technology assessment of blockchain-based technologies in the food supply chain. J. Clean. Prod. 2020, 269, 122193. [CrossRef]

23. Zeng, M.; Lu, J. The impact of information technology capabilities on agri-food supply chain performance: The mediating effects of interorganizational relationships. J. Enterp. Inf. Manag. 2020, 34, 1699-1721. [CrossRef]

24. Saurabh, S.; Dey, K. Blockchain technology adoption, architecture, and sustainable agri-food supply chains. J. Clean. Prod. 2021, 284, 124731. [CrossRef]

25. Fisher, O.; Watson, N.; Porcu, L.; Bacon, D.; Rigley, M.; Gomes, R.L. Cloud manufacturing as a sustainable process manufacturing route. J. Manuf. Syst. 2018, 47, 53-68. [CrossRef]

26. Koutsos, T.M.; Menexes, G.C.; Dordas, C.A. An efficient framework for conducting systematic literature reviews in agricultural sciences. Sci. Total Environ. 2019, 682, 106-117. [CrossRef] [PubMed]

27. Denyer, D.; Tranfield, D. Producing a Systematic Review. In The Sage Handbook of Organizationa Research Methods; Buchanan, D.A., Bryman, A., Eds.; Sage Publications Ltd.: London, UK, 2009; pp. 671-689.

28. Kitchenham, B. Guidelines for performing Systematic Literature Reviews in Software Engineering; Technical Report; Keele University: Newcastle, UK, 2007.

29. Chavarro, D.; Ràfols, I.; Tang, P. To what extent is inclusion in the Web of Science an indicator of journal 'quality'? Res. Evaluation 2018, 27, 106-118. [CrossRef]

30. Martín-Martín, A.; Orduna-Malea, E.; Thelwall, M.; López-Cózar, E.D. Google Scholar, Web of Science, and Scopus: A systematic comparison of citations in 252 subject categories. J. Inf. 2018, 12, 1160-1177. [CrossRef]

31. Mongeon, P.; Paul-Hus, A. The journal coverage of Web of Science and Scopus: A comparative analysis. Scientometrics 2016, 106, 213-228. [CrossRef]

32. Bergman, E.M.L. Finding Citations to Social Work Literature: The Relative Benefits of Using Web of Science, Scopus, or Google Scholar. J. Acad. Libr. 2012, 38, 370-379. [CrossRef]

33. Aramyan, L.H.; Lansink, A.O.; Van Der Vorst, J.G.A.J.; Van Kooten, O. Performance measurement in agri-food supply chains: A case study. Supply Chain Manag. Int. J. 2007, 12, 304-315. [CrossRef]

34. Talavera, J.M.; Tobon, L.; Gómez, J.A.; Culman, M.; Aranda, J.; Parra, D.T.; Quiroz, L.A.; Hoyos, A.; Garreta, L.E. Review of IoT applications in agro-industrial and environmental fields. Comput. Electron. Agric. 2017, 142, 283-297. [CrossRef]

35. Patrício, D.I.; Rieder, R. Computer vision and artificial intelligence in precision agriculture for grain crops: A systematic review. Comput. Electron. Agric. 2018, 153, 69-81. [CrossRef]

36. Kamilaris, A.; Fonts, A.; Prenafeta-Bold $v$ F, X. The rise of blockchain technology in agriculture and food supply chains. Trends Food Sci. Technol. 2019, 91, 640-652. [CrossRef]

37. Bibi, F.; Guillaume, C.; Gontard, N.; Sorli, B. A review: RFID technology having sensing aptitudes for food industry and their contribution to tracking and monitoring of food products. Trends Food Sci. Technol. 2017, 62, 91-103. [CrossRef]

38. Kumar, I.; Rawat, J.; Mohd, N.; Husain, S. Opportunities of Artificial Intelligence and Machine Learning in the Food Industry. J. Food Qual. 2021, 2021, 1-10. [CrossRef]

39. Bécue, A.; Praça, I.; Gama, J. Artificial intelligence, cyber-threats and Industry 4.0: Challenges and opportunities. Artif. Intell. Rev. 2021, 54, 3849-3886. [CrossRef]

40. Mavani, N.R.; Ali, J.M.; Othman, S.; Hussain, M.A.; Hashim, H.; Rahman, N.A. Application of Artificial Intelligence in Food Industry-a Guideline. Food Eng. Rev. 2021, 1-42. [CrossRef]

41. Massaro, A.; Galiano, A. Re-engineering process in a food factory: An overview of technologies and approaches for the design of pasta production processes. Prod. Manuf. Res. 2020, 8, 80-100. [CrossRef]

42. Di Vaio, A.; Boccia, F.; Landriani, L.; Palladino, R. Artificial Intelligence in the Agri-Food System: Rethinking Sustainable Business Models in the COVID-19 Scenario. Sustainability 2020, 12, 4851. [CrossRef]

43. Su, Y.; Wang, X. Innovation of agricultural economic management in the process of constructing smart agriculture by big data. Sustain. Comput. Inform. Syst. 2021, 31, 100579. [CrossRef]

44. Arora, D. Demand prognosis of industry 4.0 to agriculture sector in India. Int. J. Knowl.-Based Intell. Eng. Syst. 2021, 25, 129-138. [CrossRef]

45. Konur, S.; Lan, Y.; Thakker, D.; Morkyani, G.; Polovina, N.; Sharp, J. Towards design and implementation of Industry 4.0 for food manufacturing. Neural Comput. Appl. 2021, 1-13. [CrossRef]

46. Islam, S.; Manning, L.; Cullen, J.M. A Hybrid Traceability Technology Selection Approach for Sustainable Food Supply Chains. Sustainability 2021, 13, 9385. [CrossRef] 
47. Gallo, A.; Accorsi, R.; Goh, A.; Hsiao, H.; Manzini, R. A traceability-support system to control safety and sustainability indicators in food distribution. Food Control. 2021, 124, 107866. [CrossRef]

48. Schmetz, A.; Lee, T.H.; Hoeren, M.; Berger, M.; Ehret, S.; Zontar, D.; Min, S.-H.; Ahn, S.-H.; Brecher, C. Evaluation of Industry 4.0 Data formats for Digital Twin of Optical Components. Int. J. Precis. Eng. Manuf. Technol. 2020, 7, 573-584. [CrossRef]

49. Niknejad, N.; Ismail, W.; Bahari, M.; Hendradi, R.; Salleh, A.Z. Mapping the research trends on blockchain technology in food and agriculture industry: A bibliometric analysis. Environ. Technol. Innov. 2020, 21, 101272. [CrossRef]

50. Kayikci, Y.; Subramanian, N.; Dora, M.; Bhatia, M.S. Food supply chain in the era of Industry 4.0: Blockchain technology implementation opportunities and impediments from the perspective of people, process, performance, and technology. Prod. Plan. Control. 2020, 1-10. [CrossRef]

51. Lin, C.-F. Blockchainizing Food Law: Promises and Perils of Incorporating Distributed Ledger Technologies to Food Safety, Traceability, and Sustainability Governance. Food Drug Law J. 2019, 74, 586-612.

52. Li, X.; Huang, D. Research on Value Integration Mode of Agricultural E-Commerce Industry Chain Based on Internet of Things and Blockchain Technology. Wirel. Commun. Mob. Comput. 2020, 2020, 1-11. [CrossRef]

53. Defraeye, T.; Tagliavini, G.; Wu, W.; Prawiranto, K.; Schudel, S.; Kerisima, M.A.; Verboven, P.; Bühlmann, A. Digital twins probe into food cooling and biochemical quality changes for reducing losses in refrigerated supply chains. Resour. Conserv. Recycl. 2019, 149, 778-794. [CrossRef]

54. Demestichas, K.; Peppes, N.; Alexakis, T.; Adamopoulou, E. Blockchain in Agriculture Traceability Systems: A Review. Appl. Sci. 2020, 10, 4113. [CrossRef]

55. Stranieri, S.; Riccardi, F.; Meuwissen, M.P.; Soregaroli, C. Exploring the impact of blockchain on the performance of agri-food supply chains. Food Control. 2021, 119, 107495. [CrossRef]

56. Wang, L.; Xu, L.; Zheng, Z.; Liu, S.; Li, X.; Cao, L.; Li, J.; Sun, C. Smart Contract-Based Agricultural Food Supply Chain Traceability. IEEE Access 2021, 9, 9296-9307. [CrossRef]

57. Hu, S.; Huang, S.; Huang, J.; Su, J. Blockchain and edge computing technology enabling organic agricultural supply chain: A framework solution to trust crisis. Comput. Ind. Eng. 2021, 153, 107079. [CrossRef]

58. Chen, R.-Y. An intelligent value stream-based approach to collaboration of food traceability cyber physical system by fog computing. Food Control. 2017, 71, 124-136. [CrossRef]

59. Pal, A.; Kant, K. Smart Sensing, Communication, and Control in Perishable Food Supply Chain. ACM Trans. Sens. Netw. 2020, 16, 1-41. [CrossRef]

60. Rad, C.-R.; Hancu, O.; Takacs, I.-A.; Olteanu, G. Smart Monitoring of Potato Crop: A Cyber-Physical System Architecture Model in the Field of Precision Agriculture. Agric. Agric. Sci. Procedia 2015, 6, 73-79. [CrossRef]

61. Huang, C.-H.; Chen, P.-J.; Lin, Y.-J.; Chen, B.-W.; Zheng, J.-X. A robot-based intelligent management design for agricultural cyber-physical systems. Comput. Electron. Agric. 2021, 181, 105967. [CrossRef]

62. Koulouris, A.; Misailidis, N.; Petrides, D. Applications of process and digital twin models for production simulation and scheduling in the manufacturing of food ingredients and products. Food Bioprod. Process. 2021, 126, 317-333. [CrossRef]

63. Dey, S.; Saha, S.; Singh, A.; McDonald-Maier, K. FoodSQRBlock: Digitizing Food Production and the Supply Chain with Blockchain and QR Code in the Cloud. Sustainability 2021, 13, 3486. [CrossRef]

64. Bhatia, M.; Ahanger, T.A. Intelligent decision-making in Smart Food Industry: Quality perspective. Pervasive Mob. Comput. 2021, 72, 101304. [CrossRef]

65. Li, Q.; Li, Y.; Wang, L. Research on application of internet of things technology in quality traceability of fruit and vegetable agricultural products. J. Ambient. Intell. Humaniz. Comput. 2021, 1-8. [CrossRef]

66. Mondragon, A.E.C.; Mondragon, C.E.C.; Coronado, E.S. Managing the food supply chain in the age of digitalisation: A conceptual approach in the fisheries sector. Prod. Plan. Control. 2021, 32, 242-255. [CrossRef]

67. Sadowski, S.; Spachos, P. Wireless technologies for smart agricultural monitoring using internet of things devices with energy harvesting capabilities. Comput. Electron. Agric. 2020, 172, 105338. [CrossRef]

68. Visconti, P.; De Fazio, R.; Velázquez, R.; Del-Valle-Soto, C.; Giannoccaro, N.I. Development of Sensors-Based Agri-Food Traceability System Remotely Managed by A Software Platform for Optimized Farm Management. Sensors 2020, 20, 3632. [CrossRef]

69. Singh, R.K.; Luthra, S.; Mangla, S.K.; Uniyal, S. Applications of information and communication technology for sustainable growth of SMEs in India food industry. Resour. Conserv. Recycl. 2019, 147, 10-18. [CrossRef]

70. Chauhan, Y. Food Waste Management with Technological Platforms: Evidence from Indian Food Supply Chains. Sustainability 2020, 12, 8162. [CrossRef]

71. Ciccullo, F.; Cagliano, R.; Bartezzaghi, G.; Perego, A. Implementing the circular economy paradigm in the agri-food supply chain: The role of food waste prevention technologies. Resour. Conserv. Recycl. 2021, 164, 105114. [CrossRef]

72. De Corato, U.; Cancellara, F.A. Measures, technologies, and incentives for cleaning the minimally processed fruits and vegetables supply chain in the Italian food industry. J. Clean. Prod. 2019, 237. [CrossRef]

73. Chen, S.; Brahma, S.; Mackay, J.; Cao, C.; Aliakbarian, B. The role of smart packaging system in food supply chain. J. Food Sci. 2020, 85, 517-525. [CrossRef] [PubMed]

74. Akhoundi, A.; Nazif, S. Life-Cycle Assessment of Tertiary Treatment Technologies to Treat Secondary Municipal Wastewater for Reuse in Agricultural Irrigation, Artificial Recharge of Groundwater, and Industrial Usages. J. Environ. Eng. 2020, 146, 04020031. [CrossRef] 
75. Dadi, V.; Nikhil, S.R.; Mor, R.S.; Agarwal, T.; Arora, S. Agri-Food 4.0 and Innovations: Revamping the Supply Chain Operations. Prod. Eng. Arch. 2021, 27, 75-89. [CrossRef]

76. Dora, M.; Kumar, A.; Mangla, S.K.; Pant, A.; Kamal, M.M. Critical success factors influencing artificial intelligence adoption in food supply chains. Int. J. Prod. Res. 2021, 1-20. [CrossRef]

77. Olan, F.; Liu, S.; Suklan, J.; Jayawickrama, U.; Arakpogun, E.O. The role of Artificial Intelligence networks in sustainable supply chain finance for food and drink industry. Int. J. Prod. Res. 2021, 1-16. [CrossRef]

78. Kakani, V.; Nguyen, V.H.; Kumar, B.P.; Kim, H.; Pasupuleti, V.R. A critical review on computer vision and artificial intelligence in food industry. J. Agric. Food Res. 2020, 2, 100033. [CrossRef]

79. Singh, A.; Kumari, S.; Malekpoor, H.; Mishra, N. Big data cloud computing framework for low carbon supplier selection in the beef supply chain. J. Clean. Prod. 2018, 202, 139-149. [CrossRef]

80. Vanderroost, M.; Ragaert, P.; Verwaeren, J.; De Meulenaer, B.; De Baets, B.; Devlieghere, F. The digitization of a food package's life cycle: Existing and emerging computer systems in the pre-logistics phase. Comput. Ind. 2017, 87, 1-14. [CrossRef]

81. Fabrizio, E.; Branciforti, V.; Costantino, A.; Filippi, M.; Barbero, S.; Tecco, G.; Mollo, P.; Molino, A. Monitoring and managing of a micro-smart grid for renewable sources exploitation in an agro-industrial site. Sustain. Cities Soc. 2017, 28, 88-100. [CrossRef]

82. Oltra-Mestre, M.J.; Hargaden, V.; Coughlan, P.; del Río, B.S. Innovation in the Agri-Food sector: Exploiting opportunities for Industry 4.0. Creat. Innov. Manag. 2021, 30, 198-210. [CrossRef]

83. Lezoche, M.; Hernandez, J.E.; Díaz, M.D.M.E.A.; Panetto, H.; Kacprzyk, J. Agri-food 4.0: A survey of the supply chains and technologies for the future agriculture. Comput. Ind. 2020, 117, 103187. [CrossRef]

84. Ampatzidis, Y.; Partel, V.; Costa, L. Agroview: Cloud-based application to process, analyze and visualize UAV-collected data for precision agriculture applications utilizing artificial intelligence. Comput. Electron. Agric. 2020, 174, 105457. [CrossRef]

85. Yadav, V.S.; Singh, A.; Raut, R.D.; Govindarajan, U.H. Blockchain technology adoption barriers in the Indian agricultural supply chain: An integrated approach. Resour. Conserv. Recycl. 2020, 161, 104877. [CrossRef]

86. Dai, Y. Application of Cloud Video Information Processing Technology in Alleviating the Food Safety Trust Crisis. Int. J. Pattern Recognit. Artif. Intell. 2019, 34. [CrossRef]

87. Juan, C.; Shiling, P. Research on supply chain management of agricultural products based on RFID technology. Agro Food Ind. Hi-Tech. 2017, 28, 959-964.

88. Nayal, K.; Raut, R.; Jabbour, A.B.L.D.S.; Narkhede, B.E.; Gedam, V.V. Integrated technologies toward sustainable agriculture supply chains: Missing links. J. Enterp. Inf. Manag. 2021. Ahead-of-Print. [CrossRef]

89. Chen, X.; Voigt, T. Implementation of the Manufacturing Execution System in the food and beverage industry. J. Food Eng. 2020, 278, 109932. [CrossRef]

90. Ma, S.; Zhang, Y.; Lv, J.; Yang, H.; Wu, J. Energy-cyber-physical system enabled management for energy-intensive manufacturing industries. J. Clean. Prod. 2019, 226, 892-903. [CrossRef]

91. Maxime, D.; Marcotte, M.; Arcand, Y. Development of eco-efficiency indicators for the Canadian food and beverage industry. J. Clean. Prod. 2006, 14, 636-648. [CrossRef]

92. Yuan, Y.; Viet, N.; Behdani, B. The impact of information sharing on the performance of horizontal logistics collaboration: A simulation study in an agri-food supply chain. IFAC-PapersOnLine 2019, 52, 2722-2727. [CrossRef]

93. Morais, D.; Gaspar, P.D.; Silva, P.D.; Andrade, L.P.; Nunes, J. Energy consumption and efficiency measures in the Portuguese food processing industry. J. Food Process. Preserv. 2020, e14862. [CrossRef]

94. Ferrarez, R.P.F.; Vargas, R.V.; Alvarenga, J.C.; Chinelli, C.K.; Costa, M.D.A.; De Oliveira, B.L.; Haddad, A.N.; Soares, C.A.P. Sustainability Indicators to Assess Infrastructure Projects: Sector Disclosure to Interlock with the Global Reporting Initiative. Eng. J. 2020, 24, 43-61. [CrossRef]

95. Juchniewicz, M.; Łukiewska, K. Diversity of the international competitive performance of the food industry of the European Union member states. Agribusiness 2021, 37, 422-437. [CrossRef]

96. Costa, J.; Matias, J.C.O. Open Innovation 4.0 as an Enhancer of Sustainable Innovation Ecosystems. Sustainability 2020, $12,8112$. [CrossRef]

97. Fernandez-Mena, H.; Gaudou, B.; Pellerin, S.; MacDonald, G.K.; Nesme, T. Flows in Agro-food Networks (FAN): An agent-based model to simulate local agricultural material flows. Agric. Syst. 2019, 180, 102718. [CrossRef]

98. Ruiz-Almeida, A.; Rivera-Ferre, M.G. Internationally-based indicators to measure Agri-food systems sustainability using food sovereignty as a conceptual framework. Food Secur. 2019, 11, 1321-1337. [CrossRef]

99. Mandarino, R.A.; Barbosa, F.A.; Lopes, L.; Telles, V.; Florence, E.D.A.S.; Bicalho, F.L. Evaluation of good agricultural practices and sustaintability indicators in livestock systems under tropical conditions. Agric. Syst. 2019, 174, 32-38. [CrossRef]

100. Food and Agriculture Organization of the United Nations. Food Systems at Risk. New Trends and Challenges; FAO-CIRAD-European Commission: Rome, Italy, 2019. [CrossRef]

101. Conti., C.; Zanello, G.; Hall, A. Why are agri-food systems resistant to new directions of change? A systematic review. Global Food Secur. 2021, 31, 100576. [CrossRef]

102. Bonke, V.; Musshoff, O. Understanding German farmer's intention to adopt mixed cropping using the theory of planned behavior. Agron. Sustain. Dev. 2020, 40, 1-14. [CrossRef]

103. Gonçalves, R.B.; Dorion, E.C.H.; Nodari, C.H.; Lazzari, F.; Olea, P.M. Field burning practices in a southern region of Brazil: A path dependence analysis. Manag. Environ. Qual. Int. J. 2015, 26, 437-447. [CrossRef] 
104. Swinburn, B. Power Dynamics in 21st-Century Food Systems. Nutrients 2019, 11, 2544. [CrossRef] [PubMed]

105. Zaraté, P.; Alemany, M.; del Pino, M.; Alvarez, A.E.; Camilleri, G. How to Support Group Decision Making in Horticulture: An Approach Based on the Combination of a Centralized Mathematical Model and a Group Decision Support System. Lect. Notes Bus. Inf. Process. 2019, 348, 83-94. [CrossRef]

106. Kumar, S.; Raut, R.D.; Nayal, K.; Kraus, S.; Yadav, V.S.; Narkhede, B.E. To identify industry 4.0 and circular economy adoption barriers in the agriculture supply chain by using ISM-ANP. J. Clean. Prod. 2021, 293, 126023. [CrossRef]

107. Kamble, S.S.; Gunasekaran, A.; Sharma, R. Modeling the blockchain enabled traceability in agriculture supply chain. Int. J. Inf. Manag. 2020, 52, 101967. [CrossRef]

108. Sharma, Y.K.; Mangla, S.K.; Patil, P.P.; Liu, S. When challenges impede the process: For circular economy-driven sustainabi-lity practices in food supply chain. Manag. Decis. 2019, 57, 995-1017. [CrossRef]

109. Brozzi, R.; Forti, D.; Rauch, E.; Matt, D.T. The Advantages of Industry 4.0 Applications for Sustainability: Results from a Sample of Manufacturing Companies. Sustainability 2020, 12, 3647. [CrossRef]

110. Yadav, S.; Garg, D.; Luthra, S. Analysing challenges for internet of things adoption in agriculture supply chain management. Int. J. Ind. Syst. Eng. 2020, 36, 73. [CrossRef]

111. Rajput, S.; Singh, S.P. Industry 4.0 - challenges to implement circular economy. Benchmarking Int. J. 2021, 28, 1717-1739. [CrossRef]

112. Yadav, G.; Luthra, S.; Jakhar, S.K.; Mangla, S.K.; Rai, D.P. A framework to overcome sustainable supply chain challenges through solution measures of industry 4.0 and circular economy: An automotive case. J. Clean. Prod. 2020, 254, 120112. [CrossRef]

113. Ahi, P.; Searcy, C. An analysis of metrics used to measure performance in green and sustainable supply chains. J. Clean. Prod. 2015, 86, 360-377. [CrossRef] 